\title{
Characterization of glycoconjugates in the pharyngeal cavity and the oesophagus of Odontesthes bonariensis by lectins
}

\author{
Alcira Ofelia Díaz ${ }^{1 *}$ \\ María Florencia Tano de la Hoz ${ }^{1,3}$ \\ Alicia Mabel García 1,2 \\ Alicia Haydée Escalante 1,2 \\ Adriana Lía Goldemberg ${ }^{1}$ \\ ${ }^{1}$ Instituto de Investigaciones Marinas y Costeras, Departamento de Biología \\ Facultad de Ciencias Exactas y Naturales, CONICET - Universidad Nacional de Mar del Plata \\ Funes $32503^{\circ}$ piso, 7600 Mar del Plata, Provincia de Buenos Aires, Argentina \\ ${ }^{2}$ Consejo Nacional de Investigaciones Científicas y Técnicas, Argentina \\ ${ }^{3}$ Comisión de Investigaciones Científicas de la Provincia de Buenos Aires - CIC \\ Provincia de Buenos Aires, Argentina \\ * Corresponding author \\ adiaz@mdp.edu.ar
}

\section{Resumo}

Caracterização de glicoconjugados da cavidade faríngea e esôfago de Odontesthes bonariensis por lectinas. Sete tipos de lectinas biotiniladas foram usados para examinar padrões de expressão de glicoconjugados (GCs) da mucosa da cavidade faríngea e esôfago do Odontesthes bonariensis. Sítios de ligação para Con-A, RCA-I e WGA foram positivos para o glicocálix, células epiteliais e células mucosas em ambos os órgãos com padrões de reação similar. PNA apenas marcou o glicocálix e as células epiteliais da mucosa em ambos os órgãos. DBA, SBA e UEA-I marcaram o esôfago exclusivamente e uma maior afinidade com o glicocálix e as células epiteliais foi observada. Os resultados deste estudo foram discutidos esuas possíveis implicações funcionais foram comparadas.

Palavras-chave: Cavidade da faringe; Esôfago; Glicoconjugados; Histoquímica com lectinas; 'Silverside'

\section{Abstract}

Seven types of biotinylated lectins were used to examine glycoconjugates (GCs) expression patterns in the mucosa of the pharyngeal cavity and the oesophagus of Odontesthes bonariensis. Con-A, RCA-I, and WGA binding sites were positive for glycocalyx, epithelial cells, and mucous cells in both organs with similar reaction patterns. PNA just stained glycocalyx and epithelial cells in the mucosa in both organs. DBA, SBA, and UEA-I stained only the oesophagus, and a greater affinity to glycocalyx and the epithelial cells was observed. The results of this study were discussed and their possible functional implications were compared.

Key words: Glycoconjugates; Lectin histochemistry; Oesophagus; Pharyngeal cavity; 'Silverside' 


\section{Introduction}

'Silverside' Odontesthes bonariensis (Pisces, Atherinopsidae) is a comercially important fish species from South America which is intensively cultivated in France, Israel, Italy, and Japan (STRÜSSMANN; TAKASHIMA, 1990). Even though O. bonariensis is considered a freshwater species, there are studies indicating that freshwater may not be its optimal environment (TSUZUKI et al., 2001). This species is perhaps among the most captured ones for commerce and sport fishing in the Argentinean "pampasic" shallow lakes. Almost all studies previously carried out involve the estimation of 'silverside' stocks of eggs and larvae, as well as juvenile and adult individuals (SOMOZA et al., 2008) and reproduction in captivity (MIRANDA et al., 2006). In spite of the considerable interest in this species, little progress has been made with regard to morphological studies on 'silverside' in general (VIGLIANO et al., 2006; DÍAZ et al., 2010) and its digestive tract in particular (DÍAZ et al., 2006; VIGLIANO et al., 2011).

We have previously reported on the histology and histochemistry of the pharyngeal cavity and the oesophagus of 'silverside' (DÍAZ et al., 2006). The mucosa has longitudinal folds with a stratified epithelium, abundant mucous cells, and taste buds, which are absent in the oesophagus. Most of our histochemical research has been carried out through conventional or classical histochemical methods, which allow the recognition of carbohydrate-containing macromolecules from other components of body tissues (DÍAZ et al., 2005a; 2005b; 2006; 2008; 2010). In fishes, the digestive tract and the structures intimately related to it present changes with regard to taxonomy and feeding habits (DOMENEGHINI et al., 1998).

It's generally assumed that the digestive tract produces glycoconjugates (GCs), which are the main components of mucosubstances in vertebrates. It's known they have a variety of functions, such as lubrication, protection against microorganisms, and proteolytic degradation (MITTAL et al., 1994; DÍAZ et al., 2008). In fishes, mucosubstances also have an osmotic function, in the form of binding and transport of water and various ions (LORETZ, 1995).

Lectins, which are naturally occurring carbohydratebinding proteins other than enzymes or antibodies, are a valuable tool to characterize and localize GCs in tissues. Histochemical studies have shown the usefulness of lectins as biomarkers for specific secretory functions, structural components, and changes in cells and tissues (CHAN; HO, 1999).

Since no research has used lectin histochemistry in the mucosa of the pharyngeal cavity and the oesophagus of 'silverside', and as lectins can provide some understanding of the GCs characteristics in these organs, this study has lectin histochemistry as its basis, in order to gather information on the specific functions of mucus production.

\section{Material and Methods}

The female and male specimens of $O$. bonariensis used in this research had $24.0 \pm 2.0 \mathrm{~cm}$ in length, $180.0 \pm 5.0 \mathrm{~g}$ in weight; they were collected in Los Padres Lagoon (Province of Buenos Aires, Argentina), 37 $56^{\prime} 30^{\prime}$ 'S, 5744'30”'W, and immediately transported to the laboratory in containers filled with water. Fishes were anaesthetized with Tricaine (MS-222) before being measured, weighed, and sexed. The digestive tract was rapidly removed and samples from the pharyngeal cavity and oesophagus were fixed by immersion in $10 \%$ buffered formalin before dehydration in an ethanol series, and embedded in paraffin. The care and use of experimental animals complied with the guidelines of the Safety Comittee of Universidad Nacional de Mar del Plata.

Lectins staining methodologies were performed according to Gimeno et al. (1995). Seven different specific lectins were used (Table 1). All of them were purchased at Vector Laboratories, Inc. (Burlingame, CA, USA). Paraffin-embedded sections mounted on 
slides coated with Poly-L-Lisine (Sigma Diagnostics, St. Louis, MO, USA) were deparaffinized with xylene. They were next incubated in $0.3 \% \mathrm{H}_{2} \mathrm{O}_{2}$ in methanol for $30 \mathrm{~min}$ at room temperature, in order to block endogenous peroxidase activity. They were then hydrated, washed in $0.01 \mathrm{M}$ phosphate-buffered saline (PBS), $\mathrm{pH} 7.2$, and treated with $0.1 \%$ bovine serum albumin in PBS for $15 \mathrm{~min}$, to inhibit non-specific binding. Sections were then incubated with biotinylated lectins for $30 \mathrm{~min}$ at room temperature and rinsed in PBS for $15 \mathrm{~min}$. After that, sections were treated with avidin biotin-peroxidase complex (ABC) (Vector Laboratories, Inc, Burlingame, CA, USA) for $45 \mathrm{~min}$. The horseradish peroxidase was activated by incubation for $4-10 \mathrm{~min}$ with a buffered $0.05 \mathrm{M}$ Tris- $\mathrm{HCl} \mathrm{pH} 7.6$ solution containing $0.02 \%$ diaminobenzidine (DAB) and $0.05 \% \mathrm{H}_{2} \mathrm{O}_{2}$. Each lectin was used at a $30 \mu \mathrm{g} / \mathrm{ml}$ dilution in PBS, except PNA, which was applied at a $10 \mu \mathrm{g} / \mathrm{ml}$ concentration. Two types of control were performed: (1) lectin solution was replaced by PBS; and (2) lectin labeling was performed as described above, after lectins were preincubated for $1 \mathrm{~h}$ in the presence of appropriate hapten sugars (0.2M in PBS), as listed in Table 1, at room temperature.

Evaluation of labeling intensities was based on subjective estimates by all authors after examination of two sections per sample of all animals tested.
TABLE 1: Lectin used and their carbohydrate specificities.

\begin{tabular}{|c|c|c|}
\hline Lectin & Acronym & Specificity/hapten sugara,b \\
\hline $\begin{array}{l}\text { Canavalia ensiformis } \\
\text { agglutinin }\end{array}$ & Con-A & $\alpha$-D-Man; $\alpha$-D-Glc \\
\hline $\begin{array}{l}\text { Triticum vulgaris } \\
\text { agglutinin }\end{array}$ & WGA & $\beta$-D-GlcNac; NeuNAc \\
\hline $\begin{array}{l}\text { Dolichos biflorus } \\
\text { agglutinin }\end{array}$ & DBA & $\alpha$-D-GalNAc \\
\hline Glycine max agglutinin & SBA & $\alpha$-D-GalNAc; $\beta$-D-GalNAc \\
\hline $\begin{array}{l}\text { Arachis hypogaea } \\
\text { agglutinin }\end{array}$ & PNA & $\beta$-D-Gal $(\beta 1->3)$ D-GalNAc \\
\hline $\begin{array}{l}\text { Ulex europaeus } \\
\text { agglutinin-I }\end{array}$ & UEA-I & $\alpha$-L-Fuc \\
\hline $\begin{array}{l}\text { Ricinus communis } \\
\text { agglutinin-I }\end{array}$ & RCA-I & $\beta$-Gal; $\beta$-GalNAc \\
\hline
\end{tabular}

${ }^{\mathrm{a} G o l d s t e i n ; ~ H a y e s ~(1978) . ~ ' ~} \mathrm{Fuc}$, fucose; Gal, galactose; GalNAc, $\mathrm{N}$-acetylgalactosamine; Glc, glucose; GlcNAc, N-acetylglucosamine; Man, mannose; NeuNAc, acetylneuraminic acid (sialic acid).

\section{Results}

The results of lectin histochemistry used to reveal GCs in the mucosa of the pharyngeal cavity and the oesophagus of $O$. bonariensis are summarized in Table 2 .

Con-A binding sites were mainly observed at a glycocalyx level and in epithelial cells, and less importantly in mucous cells from the pharyngeal cavity and oesophagus (Figure 1A, C). WGA showed a moderate affinity to the glycocalyx, epithelial cells and mucous cells in both organs (Figure 1E, e). Binding sites

TABLE 2: Lectin binding in Odontesthes bonariensis pharyngeal cavity and oesophagus.

\begin{tabular}{lcccccc} 
& \multicolumn{3}{c}{ Pharyngeal cavity } & \multicolumn{3}{c}{ Oesophagus } \\
\cline { 2 - 7 } & Mucous cells & Epithelial cells & Glycocalyx & Mucous cells & Epithelial cells & Glycocalyx \\
\hline Con-A & 1 & 2 & $2-3$ & 1 & 2 & $2-3$ \\
WGA & 2 & $1-2$ & 2 & 2 & $1-2$ & $1-2$ \\
DBA & 0 & 0 & 0 & 0 & $0-1$ & 1 \\
SBA & 0 & 0 & 0 & $0-1$ & 2 & 2 \\
PNA & $0-1$ & 0 & $0-1$ & $0-1$ & 0 & 1 \\
UEA-I & 0 & 0 & 0 & 0 & 1 & 2 \\
RCA-I & 2 & 1 & 2 & $2-3$ & 1 & $2-3$ \\
\hline
\end{tabular}

Numbers indicate staining intensity on a subjective scale: 0 unstained; 1 weak; 2 moderate; 3 strong. 
for DBA were only observed in the glycocalyx and the epithelial cells of oesophagus. SBA stained only the oesophagus, where a greater affinity was evidenced in the glycocalyx and epithelial cells. Mucous cells were labeled weakly with SBA lectin (Figure 1D). PNA scarcely stained the glycocalyx and mucous cells of both organs. Epithelial cells were unstained. Binding sites for UEA-I were visualized in the glycocalyx and the epithelial cells of oesophagus, although not in the pharyngeal cavity. RCA-I showed a similar positive reaction pattern in both organs, albeit mucous cells and glycocalyx of oesophagus showed a higher labeling (Figure 1B). No labeling was detected in control sections (Figure 1F).

\section{Discussion}

Using lectin histochemistry, it was possible to establish the heterogeneity of GCs present in cells of the pharyngeal cavity and the oesophagus of $O$. bonariensis.

FIGURE 1: Lectin histochemistry of the pharyngeal cavity and oesophagus of $O$. bonariensis. Pharyngeal cavity: (A) Con-A. Scale bar $=28 \mu \mathrm{m}$. (B) RCA-I. Scale bar $=78 \mu \mathrm{m}$. Oesophagus: (C) Con-A. Scale bar $=34 \mu \mathrm{m}$. (D) SBA. Scale bar $=39 \mu \mathrm{m}$. (E) WGA. Scale bar $=25 \mu \mathrm{m}$. (e) WGA. Scale bar $=30 \mu \mathrm{m}$. (F) Control. Scale bar $=40 \mu \mathrm{m}$. Adherent mucus gel (arrow) and mucus cells (asterisk).
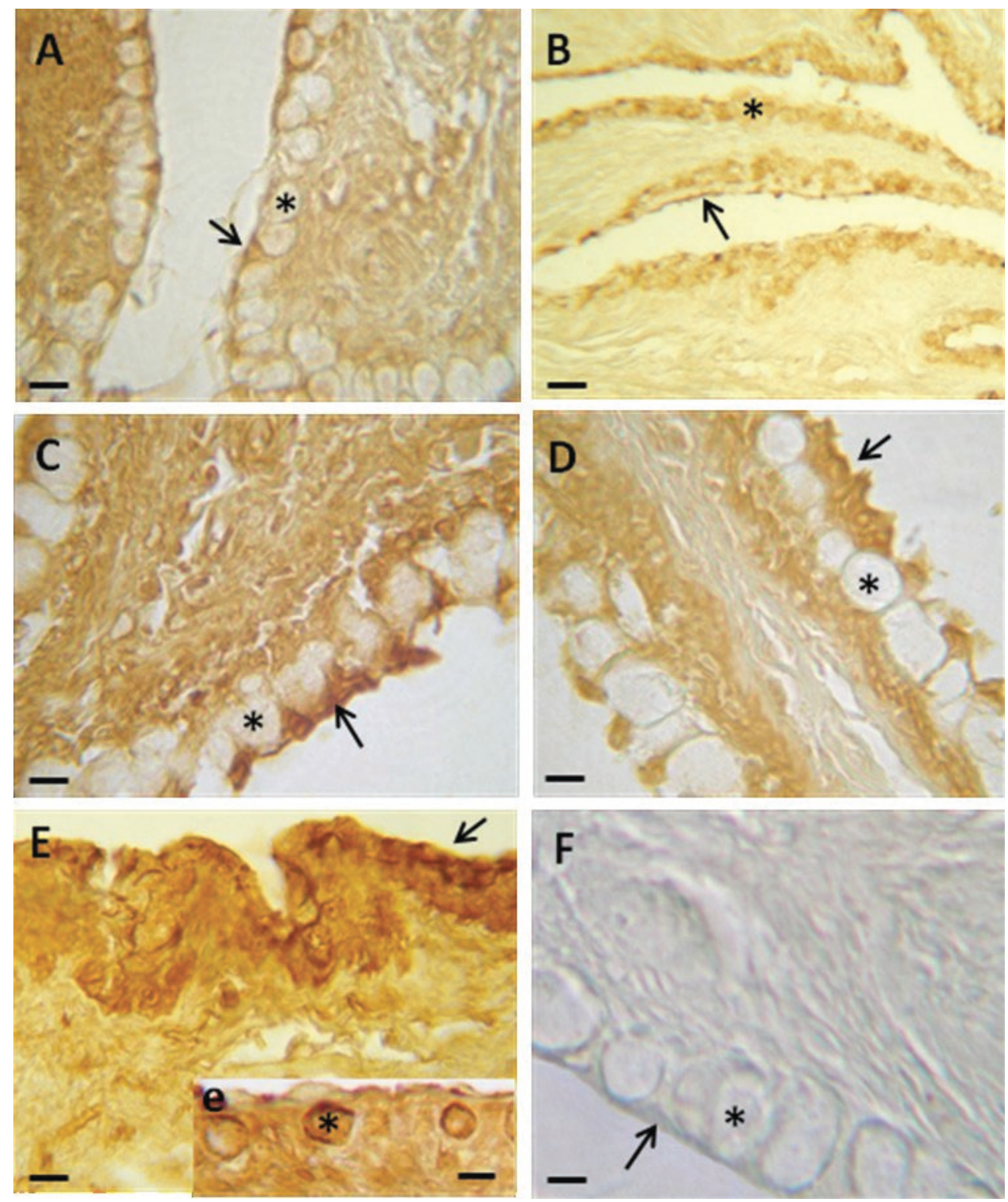
The oligosaccharide chains of GCs have been categorized into two families: N- and O-linked oligosaccharides. The first group classically contains a reducing terminal $\mathrm{N}$-acetylglucosamine (GlcNAc) $\mathrm{N}$-glycosidically bound to asparagine. The O-linked oligosaccharide (mucin type) is characterized by a reducing $\mathrm{N}$-acetylgalactosamine (GalNAc) terminal $\mathrm{O}$-glycosidically linked to serine or threonine. These amino acid residues can also link fucose (Fuc), glucose (Glc), mannose (Man), and $\mathrm{N}$-acetylglucosamine (GlcNac) to form other classes of O-linked glycans (DESANTIS et al., 2006; PARRILLO et al., 2009). The oligosaccharides of GCs N- and O-chains are correlated to different functions, such as lubrication, absorption, and transport of molecules through the membranes, protection against proteolytic degradation, and inhibition of microorganisms. The study of carbohydrate chains composition and their location in a specific alimentary canal could help understanding their functions in digestive processes.

Whereas most lectins reacted in like manner both in the pharyngeal cavity and the oesophagus, differences arose with DBA, SBA, and UEA-I, which were positive only in epithelial cells from the oesophagus. The presence of a large variety of carbohydrates indicates not only a simple function in protecting or lubricating the mucosa of the alimentary canal against chemical or mechanical injuries, but also other functions, including cooperation in pre-gastric digestion (MARCHETTI et al., 2006).

This corroborates other researches indicating that in some fish species digestion starts in the oesophagus and continues in the stomach (DOMENEGHINI et al., 1998). Likewise, the high level of histochemical complexity in the oesophagus could be related to the absence of salivary glands (SCOCCO et al., 1996). It's important to notice that digestion in mammals starts in the mouth, due to the presence of secretion from the salivary glands. Therefore, the oesophageal mucous cells can replace the secretory function of salivary glands in lubricating the wall of the oesophagus (PEDINI et al., 2004; MARCHETTI et al., 2006; DÍAZ et al., 2008).

The results with DBA and SBA for $O$. bonariensis corroborate the existence of GalNAc. DBA binds especially to $\alpha$-D-GalNAc, indicating the presence, although scarce, of this glucidic residue in the glycocalyx and epithelial cells of oesophagus, whereas SBA doesn't have anomeric specificity.

Con-A, like other Man-binding lectins, has been used to identify GCs containing N-linked oligosaccharides, since O-linked oligosaccharides contain less than 1\% Man (SPICER; SCHULTE, 1992). In accordance with other fish species, the surface cells of both organs have mannose residues, with a probable protective role against bacterial infections (LEMAITRE et al., 1996; BURKHARDT-HOLM, 1997; DÍAZ et al., 2005b). In addition, a protective role of mannose residues was also described by Lemaitre et al. (1996) in the skin of carp.

WGA exhibits a strong affinity to sialic acid at its terminal position, indicating the location of this carbohydrate in the mucous cells, in the epithelial cells and in the glycocalyx in both organs. As in this study, sialic acid has been found in several fish species through histochemical methods and chemical analyses (GENTEN; DANGUY, 1990; DÍAZ et al., 2008; 2010). Glycoconjugates in mucus are major determinants of mucus viscosity, and the acidic glycoproteins of the sialylated type are indicative of a rather fluid mucosal secretion which improves prey sliding within the oesophageal lumen by reducing viscous drag (DOMENEGHINI et al., 1999; MEYER et al., 2009). Moreover, sialic acids are essential components of receptors, e.g. the capacity of viruses and toxins of infecting cells depends on the presence of these acids in the cell membranes (PAJAK; DANGUY, 1993). On the contrary, the weakly or non-lectin binding with UEA-I, indicative of lack of fucose, corroborates previous studies reporting on gills and epidermis of fish (ALBANAW et al., 2009; DÍAZ et al., 2010).

Although in an earlier study (DÍAZ et al., 2006) traditional histochemistry failed to show different types of mucosubstances in the pharyngeal cavity and the oesophagus, here it was proven to be true. It's worth underlining that a discrepancy between traditional and lectin histochemistry had already been found (DESANTIS et al., 2007). 
Differences in the mucus composition of both organs are probably related to different functions. Mucus in the pharyngeal cavity is likely to be involved in lubricating and protecting epithelium from mechanical injuries and bacterial invasion. Though 'silverside' is considered a freshwater fish, environments with intermediate salinities might be most favorable (TSUZUKI et al., 2000). Considering the plasticity of 'silverside', it's possible that the presence of added mucosubstances in the oesophagus might enable a response to changes in the environmental conditions early on.

\section{Acknowledgements}

This study was partly supported by the grant EXA 491/10 from Universidad Nacional de Mar del Plata (UNMdP).

\section{References}

AL-BANAW, A.; KENNGOTT, R.; AL-HASSAN, J. M.; MEHANA, N.; SINOWATZ, F. Histochemical Analysis of Glycoconjugates in the Skin of a Catfish (Arius Tenuispinis, Day). Anatomia, Histologia, Embryologia, Berlin, v. 39, p. 42-50, 2009. BURKHARDT-HOLM, P. Lectin histochemistry of rainbow trout (Oncorhynchus mykiss) gill and skin. The Histochemical Journal, Dordrecht, Boston, London, v. 29, n. 11-12, p. 893-899, 1997.

CHAN, F. L.; HO, S. M. Comparative study of glycoconjugates of the rat prostatic lobes by lectin histochemistry. The Prostate, Hoboken, v. 38, n. 1, p. 1-16, 1999.

DESANTIS, S.; VENTRIGLIA, G.; SUBAN, D.; DEFLORIO, M.; MEGALOFONOU, P.; ACONE, F.; ZARRILLI, A.; PALMIERI, G.; DE METRIO, G. Histochemical analysis of glycoconjugates in the domestic cat testis. Histolology and Histopathology, Murcia, v. 21, p. 11-22, 2006.

DESANTIS, S.; CIRILLO, F.; DEFLORIO, M.; MEGALOFONOU, P.; PALAZÓN, J. L.; SARASQUETE, C.; DE METRIO, G. Histochemical study of glycoconjugates in the toadfish Halobatrachus didactylus oesophagus epithelium. Histology and Histophatology, Murcia, v. 22, p. 23-35, 2007.

DÍAZ, A. O.; GARCÍA, A. M.; DEVINCENTI, C. V.; GOLDEMBERG, A. L. Ultrastructure and histochemical study of glycoconjugates in the gills of the white croaker (Micropogonias furnieri). Anatomia, Histologia, Embryologia, Berlin, v. 34, p. 117-122, 2005a.

DÍAZ, A. O.; GARCÍA, A. M.; GOLDEMBERG, A. L. Glycoconjugates in the branchial mucous cells of Cynoscion guatucupa (cuvier, 1830) (Pisces: Sciaenidae). Scientia Marina, Barcelona, v. 69, p. 545-553, 2005b.

DÍAZ, A. O.; ESCALANTE, A. H.; GARCÍA, A. M.; GOLDEMBERG, A. L. Histology and Histochemistry of the
Pharyngeal Cavity and Oesophagus of the Silverside Odontesthes bonariensis (Cuvier and Valenciennes). Anatomia, Histologia, Embryologia, Berlin, v. 35, p. 42-46, 2006.

DÍAZ, A. O.; GARCÍA, A. M.; GOLDEMBERG, A. L. Glycoconjugates in the mucosa of the digestive tract of Cynoscion guatucupa: A histochemical study. Acta Histochemica, Amsterdam, v. 110, p. 76-85, 2008.

DÍAZ, A. O.; GARCÍA, A. M.; ESCALANTE, A. H.; GOLDEMBERG, A. L. Glycoproteins histochemistry of the gills of Odontesthes bonariensis (Teleostei, Atherinopsidae). Journal of Fish Biology, Perthshire, v. 77, p. 1665-1673, 2010.

DOMENEGHINI, C.; PANNELLI STRAINI, R.; VEGGETTI, A. Gut glycoconjugates in Sparus aurata L. (Pisces, Teleostei). A comparative histochemical study in larval and adult ages. Histology and Histopatholgy, Murcia, v. 13, p. 359-372, 1998.

DOMENEGHINI, C.; ARRIGHI, S.; RADAELLI, G.; BOSI, G.; MASCARELLO, F. Morphological and histochemical peculiarities of the gut in the white sturgeon, Acipenser transmontanus. European Journal of Histochemistry, Pavian, v. 43, p. 135-145, 1999.

GENTEN, F; DANGUY, A. A comparative histochemical analysis of glycoconjugates in secretory cell of fish epidermis by use of biotinylated lectins. Zeitschrift fur Mikroskopisch-Anatomische Forschung, Germany, v. 104, p. 835-855, 1990.

GIMENO, E. J.; MASSONE, A. R.; MARINO, F. P.; IDIART, J. R. Intermediate filament expression and lectin histochemical features of canine transmissible venereal tumour. Acta Pathologica, Microbiologica et Immunologica Scandinavica, Copenhagen, v. 103, p. 645-650, 1995.

GOLDSTEIN, I. J.; HAYES, C. G. The lectins: carbohydrate binding proteins of plants and animals. Advances in carbohydrate chemistry and biochemistry, Washington, v. 35, p. 127-340, 1978. LEMAITRE, C.; ORANGE, N.; SAGLIO, P.; SAINT, N.; GAGNON, J.; MOLLE, G. Characterization and ion channel activities of novel antibacterial proteins from the skin mucosa of carp (Cyprinus carpio). European Journal of Biochemistry, Cambridge, v. 240, p. 143-149, 1996.

LORETZ, C. A. Electrophysiology of ion transport in teleost intestinal cells. In: WOOD, C. H.; SHUTTLEWORTH, T. J. (Eds). Cellular and molecular approaches to fish ionic regulation. London: Academic Press, 1995. p. 25-26.

MARCHETTI, L.; CAPACCHIETTI, M.; SABBIETI, M. G.; ACCILI, D.; MATERAZZI, G.; MENGHI, G. Histology and carbohydrate histochemistry of the alimentary canal in the rainbow trout Oncorynchus mykiss. Journal of Fish Biology, Perthshire, v. 68, p. 1808-1821, 2006.

MEYER, W.; LUZ, S.; SCHNAPPER, A. Lectin histochemical aspects of mucus function in the oesophagus of the Reticulated Python (Python reticulates). Anatomia, Histologia, Embryologia, Berlin, v. 38, p. 316-318, 2009.

MIRANDA, L. A.; BERASAIN, G. E.; VELASCO, C. A. M.; SHIROJO, Y.; SOMOZA, G. M. Natural spawning and intensive culture of pejerrey Odontesthes bonariensis juveniles. Biocell, Mendoza, v. 30, n. 1, p. 157-162, 2006.

MITTAL, A. K.; UEDA, T.; FUJIMORI, O.; YAMADA, K. Histochemical analysis of glycoproteins in the unicellular glands in the epidermis of an Indian freshwater fish Mastacembelus pancalus 
(Hamilton). The Histochemical Journal, Dordrecht, Boston, London, v. 26, p. 666-677, 1994.

PAJAK, B.; DANGUY, A. Characterization of sugar moieties and oligosaccharide sequences in the distal intestinal epithelium of the rainbow trout by means of lectin histochemistry. Journal of Fish Biology, Perthshire, v. 43, p. 709-722, 1993.

PARRILLO, F.; ARIAS, M. P.; VERINI SUPPLIZI, A. Glycoprofile of the different cell types present in the mucosa of the horse guttural pouches. Tissue and Cell, Siena, v. 41, p. 257-265, 2009.

PEDINI, V.; DALL'AGLIO, C.; PARILLO, F.; SCOCCO, P. A lectin histochemical study of the esophagus of shi drum. Journal of Fish Biology, Perthshire, v. 64, p. 625-31, 2004.

SCOCCO, P.; MENGHI, G.; CECCARELLI. Glycohistochemistry of the Tilapia spp. Stomach. Journal of Fish Biology, Perthshire, v. 49, p. 584-593, 1996.

SOMOZA, G. M.; MIRANDA, L. A.; BERASAIN, G. E.; COLAUTTI, D.; LENICOV, M. R.; STRÜSMANN, C. A. Historical aspects, current status and prospects of pejerrey aquaculture in South America. Aquaculture Research, Ensenada, v. 39, p. 784 793, 2008.

SPICER, S. S.; SCHULTE, B. A. Diversity of cell glycoconjugates shown histochemically: A perspective. Journal of Histochemistry and Cytochemistry, Denmark, v. 40, p. 1-38, 1992.
STRÜSSMANN, C. A.; TAKASHIMA, F. Hepatocyte nuclear size and nutritional condition of larval pejerrey, Odontesthes bonariensis (Cuvier et Valenciennes). Journal of Fish Biology, Perthshire, v. 36, p. 59-65, 1990.

TSUZUKI, M. Y.; AIKAWA, H.; STRÜSSMANN, C. A.; TAKASHIMA, F. Comparative survival and growth of embryos, larvae, and juveniles of pejerrey Odontesthes bonariensis and Odontesthes hatacheri at different salinities. Journal of Applied Ichthyology, Berlin, v. 16, p. 126-130, 2000.

TSUZUKI, M. Y.; OGAWA, K.; STRÜSSMANN, C. A.; MAITA, M.; TAKASHIMA, F. Physiological responses during stress and subsequent recovery at different salinities in adult pejerrey Odontesthes bonariensis. Aquaculture, Boston, v. 200, p. 349-362, 2001.

VIGLIANO, F. A.; ALEMAÑ, N.; QUIROGA, M. I.; NIETO J. M. Ultrastructural characterization of gills in juveniles of the Argentinian Silverside, Odontesthes bonariensis (Valenciennes, 1835) (Teleostei: Atheriniformes). Anatomia, Histologia, Embryologia, Berlin, v. 35, p. 76-83, 2006.

VIGLIANO, F. A.; MUÑOZ, L.; HERNÁNDEZ, D.; CERUTTI, P.; BERMÚDEZ, R.; QUIROGA, M. I. An immunohistochemical study of the gut neuroendocrine system in juvenile pejerrey Odontesthes bonariensis (Valenciennes). Journal of Fish Biology, Perthshire, v. 78, n. 3, p. 901-911, 2011. 